\title{
Medial-to-Lateral Gradient of Neostriatal NGF Receptors: Relationship to Cholinergic Neurons and NGF-like Immunoreactivity
}

\author{
C. Anthony Altar, Millicent Dugich-Djordjevic, Mark Armanini, and Charles Bakhit \\ Developmental Biology, Genentech, Incorporated, South San Francisco, California 94080
}

\begin{abstract}
High-affinity binding sites for recombinant human NGF (rhNGF) were studied in the caudate-putamen of the adult rat and rabbit. Displaceable ${ }^{125}$-rhNGF binding sites were densely distributed throughout the caudate-putamen and were 2-3-fold more prevalant in the ventrolateral and lateral than in the medial caudate-putamen. The amount of nondisplaceable binding did not vary throughout the caudate-putamen. The medial-to-lateral receptor gradient was correlated $(r=+0.99)$ with a 2-3-fold medial-to-lateral increase in ChAT activity. In contrast, NGF-like immunoreactivity (NGFLI) was prevalent but uniformly distributed in the caudateputamen. Lesions of intrinsic cholinergic neurons by quinolinic acid produced extensive gliosis in the medial, central, and lateral caudate-putamen, yet ${ }^{125 I}$-rhNGF binding was decreased in each of these regions. The activity of ChAT and 125|-rhNGF binding throughout the caudate-putamen were each decreased by $\mathbf{4 0} \%$ following quinolinic acid. Binding

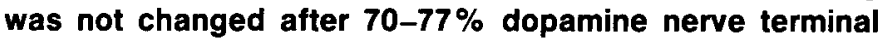
depletions induced by 6-hydroxydopamine, demonstrating a nonglial, nondopaminergic locus for striatal NGF binding sites. The cholinergiclike topography of NGF binding sites throughout the intact caudate-putamen, the parallel decreases of cholinergic neurons and NGF binding sites following intrinsic neuronal loss, and the uniform neostriatal gradient of NGF-LI are consistent with the trophic role of endogenous NGF for cholinergic interneurons of the caudate-putamen.
\end{abstract}

Recent studies have revealed a trophic role of NGF for cholinergic interneurons of the caudate-putamen of neonatal rats (Mobley et al., 1985, 1989; Aloe, 1987; Vantini et al., 1989) and adult rats (Gage et al., 1989; Hagg et al., 1989). These studies are consistent with the presence of NGF protein (Korsching et al., 1985) and mRNA (Shelton and Reichardt, 1986) in the neostriatum. However, the topography, neuronal locus, and even the presence of binding sites for NGF in the neostriatum have been unclear. A mouse monoclonal antibody, $192 \mathrm{IgG}$, recognizes both the low- and the high-affinity forms of the NGF receptor. In most studies, these sites were not found in the rat or human caudate-putamen (Hefti et al., 1986; Taniuchi et al.,

\footnotetext{
Received July 9, 1990; revised Oct. 2, 1990; accepted Oct. 26, 1990.

We gratefully acknowledge the statistical assistance of Ellen Gilkerson, the iodination of rhNGF by Gregory Bennett, the expertise of Lisa Tealer and James Lofgren with the PC12 assay, and the careful review of the manuscript by Dr. Michael Cronin.

Correspondence should be addressed to Dr. C. Anthony Altar, Developmental Biology Department, Genentech, Inc., 460 Point San Bruno Boulevard, South San Francisco, CA 94080.

Copyright (c) 1991 Society for Neuroscience $0270-6474 / 91 / 110828-09 \$ 03.00 / 0$
}

1986; Batchelor et al., 1988; Pioro and Cuello, 1988; Schatteman et al., 1988; Gage et al., 1989; Gomez-Pinilla et al., 1989; Hefti and Mash, 1989). A few immunostaining studies identified neostriatal NGF receptors but only in the ventrolateral rat caudate-putamen (Kordower et al., 1988; Gibbs et al., 1989; Kiss and Patel, 1989; Woolf et al., 1989) or a reduced number of sites in the medial caudate-putamen (Pioro and Cuello, 1990). These NGF-receptor-positive neurons are colocalized with a small proportion of neurons that contain the definitive ACh neuronal marker ChAT (Kordower et al., 1988; Kiss and Patel, 1989; Woolf et al., 1989).

The binding of iodinated murine NGF (125I-muNGF) to a high-affinity site has also been detected in homogenates of rat neostriatum (Riopcllc ct al., 1987; Mobley et al., 1989). The anatomical mapping of these sites has been achieved with tissue sections labeled with ${ }^{125}$ I-muNGF, washed in ethanol and organic solvents, and immersed in a liquid photoemulsion coating (Richardson et al., 1986; Raivich and Kreutzberg, 1987; Riopelle et al., 1987). This procedure has identified sparse populations of high-affinity NGF binding sites that are uniformly distributed in the neostriatum (Richardson et al., 1986; Raivich and Kreutzberg, 1987). Although ${ }^{125}$ I-muNGF binding sites measured in a small portion of the neostriatum are colocalized with cholinergic neurons (Riopelle et al., 1987), the uniform distribution of muNGF binding sites is not consistent with the 2-3-fold medial-to-lateral gradient for cholinergic markers in the neostriatum (Guyenet et al., 1977; Rea and Simon, 1981; Marien et al., 1987). Emulsion autoradiography with muNGF may not have detected such a gradient for a variety of technical reasons.

We have used ${ }^{125}$ I-labeled recombinant human NGF (125IrhNGF) and quantitative dry-film autoradiography with computerized image analysis to localize high-affinity NGF binding sites throughout the rat brain (Altar et al., 1991). These procedures avoid the losses of bound ligand that typically occur with the ethanol and organic solvent washes used with emulsion autoradiography (Kuhar and Unnerstall, 1982). In contrast to prior immunohistochemistry or emulsion autoradiography studies, a dense population of saturable ${ }^{125}$-rhNGF binding sites was found in the neostriatum (Altar et al., 1991). These sites bound rhNGF with high and equal affinity in the lateral and medial thirds of the neostriatum ( $K_{d}$ values of 52 and $70 \mathrm{pM}$, respectively), and the maximal density $\left(B_{\max }\right)$ of ${ }^{125}$ l-rhNGF sites was about 2-fold greater in the lateral than in the medial caudateputamen. The present study quantified the topography of NGF binding sites throughout the intact neostriatum and their relationship to ChAT and NGF-like immunoreactivity (NGF-LI). The response of NGF receptors and cholinergic neurons to neurotoxin-induced degeneration of striatal interneurons or dopamine nerve terminals was also investigated. 


\section{Materials and Methods}

Animals and surgical treatments. Male Sprague-Dawley rats (2-3 months of age) were provided by Simonsen (Gilroy, CA). Six animals received a left intrastriatal injection of $150 \mathrm{nmol}$ quinolinic acid dissolved in 2 $\mu \mathrm{l}$ phosphate-buffered saline (PBS) at a pH of 7.3 (Schwarcz et al., 1983) infused $0.5 \mathrm{~mm}$ caudal to the bregma suture, $3.5 \mathrm{~mm}$ lateral to the midline, and $6.2 \mathrm{~mm}$ ventral to the surface of the skull. An additional 12 animals received an infusion into the left central caudate-putamen of $1.5 \mu \mathrm{l}$ of the sterile $0.9 \%$ saline vehicle containing $0.1 \%$ ascorbic acid or an infusion into the left caudate-putamen of $25 \mu \mathrm{g}$ 6-hydroxydopamine dissolved in the vehicle (all reagents from Sigma Chemical Co., St. Louis, MO, unless indicated otherwise). The coordinates for the 6-hydroxydopamine injection were $0.5 \mathrm{~mm}$ rostral to bregma, $3 \mathrm{~mm}$ lateral to the midline suture, and $6.2 \mathrm{~mm}$ ventral to the skull surface. Animals were allowed to survive for 1 week (quinolinic acid) or 1 or 4 weeks (6-hydroxydopamine).

Intact or surgically operated rats or 2 New Zealand albino adult male rabbits (Elkhorn Farms, Watsonville, CA) were killed by carbon dioxide asphyxiation or sodium pentobarbital overdose, respectively. For binding assays, the 5 or 6 brains in each group were frozen in isopentane at $-15^{\circ} \mathrm{C}$. Serial $12-\mu \mathrm{m}$-thick coronal sections of rat brain were collected between $1.0 \mathrm{~mm}$ rostral to the bregma suture and $0.26 \mathrm{~mm}$ caudal to bregma (Fig. 1, left side) and from homologous regions of the rabbit neostriatum. Sections were thaw-mounted onto gelatin-coated glass microscope slides and stored at $-70^{\circ} \mathrm{C}$ for up to 1 month. For neurochemical measurements, each brain was removed from the calvarium and chilled for 2-3 min on ice. Coronal slices of $1 \mathrm{~mm}$ thickness were taken from the same region of the brain used for the binding studies with other animals (Fig. 1, right side). Neostriatal subregions from 4 5 brains were dissected on ice within $4 \mathrm{~min}$ of death, pooled, and homogenized in $4^{\circ} \mathrm{C}$ buffer (Korsching and Thoenen, 1983). Four of these pooled tissue homogenates were assayed for ChAT and NGF-LI.

$r h N G F$. Chinese hamster ovary-cell-derived rhNGF was provided by Dr. Gene Burton (Genentech, Inc.). The rhNGF was concentrated 2050 -fold and fractionated by both anion and cation exchange chromatography. The final purity of $98 \%$ was achieved employing reverse-phase HPLC (Petrides and Shooter, 1986) and identified by Coomassie-stained SDS gel scanning (Laemmli, 1970) to contain mostly rhNGF species of 118 and 120 amino acids (L. E. Burton, unpublished observations). The fractions were pooled, concentrated by an Amicon stirred cell (YM-10 membrane), and dialyzed overnight into $25 \mathrm{~mm}$ Tris, $0.1 \mathrm{M} \mathrm{NaCl}(\mathrm{pH}$, 7.0) buffer. Material was sterile filtered and stored at $4^{\circ} \mathrm{C}$. The rhNGF aliquots were also monitored for bioactivity using the pheochromocytoma (PC12) culture system (Greene and Rukenstein, 1989), using muNGF as a standard (Collaborative Research, Bedford, MA). The $\mathrm{PC} 12$ assay is sensitive to variations in rhNGF concentration in the range of $6.25-100 \mathrm{pg} \mathrm{rhNGF} / \mathrm{ml}$ with a coefficient of variation of 10 $20 \%$. The rhNGF showed stimulatory activity with an $\mathrm{EC}_{50}$ of 39 and $52 \mathrm{pg} / \mathrm{ml}$ in 2 experiments conducted in separate laboratories.

Iodination of $r h N G F$. rhNGF was iodinated by a modification of the method of De Larco et al. (1981). Fifty microliters of $1.5 \mathrm{M}$ potassium phosphate and $2 \mathrm{mCi}$ per $20 \mu \mathrm{l}$ of $\mathrm{Na}^{125}$ (Amersham, $\mathrm{Ar}$ lington Heights, VA) were added to $20 \mu \mathrm{g} / 24 \mu \mathrm{l}$ of rhNGF (average rhNGF concentration of $5.5 \mu \mathrm{M}$ during iodination). Chloramine-T $(0.1$ $\mathrm{mg} / \mathrm{ml}$ in PBS) was added in 3 sequential doses of $4 \mu \mathrm{g} / 40 \mu \mathrm{l}$ followed by incubations of $2,1.5$, and $1 \mathrm{~min}$, respectively. The reaction was quenched with $40 \mu \mathrm{l}$ of $50 \mathrm{~mm} \mathrm{~N}$-acetyl-L-tyrosine and $40 \mu \mathrm{l}$ of $1 \mathrm{M}$ potassium iodide. A $200-\mu \mathrm{l}$ volume of $8 \mathrm{M}$ urea- $\mathrm{HCl}(\mathrm{pH}, 2.3)$ was added, and the mixture was loaded onto a Vydac C-18 reverse-phase HPLC column where the rhNGF was eluted with an acetonitrile/trifluoroacetic acid (TFA) $/ \mathrm{H}_{2} \mathrm{O}$ gradient (20-45\% acetonitrile in $0.1 \%$ TFA over $25 \mathrm{~min}$ ). Peak fractions were pooled and neutralized with $50 \mu \mathrm{l}$ of $1.5 \mathrm{M}$ potassium phosphate $(\mathrm{pH}, 7.4)$. The ${ }^{125} \mathrm{I}-\mathrm{rhNGF}$ was labeled to a specific activity of $125 \mu \mathrm{Ci} / \mu \mathrm{g}(3226 \mathrm{Ci} / \mathrm{mmol} \mathrm{rhNGF}$ dimer), as determined with an ELISA for rhNGF (Bennett et al., 1990). The acetonitrile was evaporated under nitrogen, and the tracer solution was diluted 1000 -fold for use in the binding assay. The ${ }^{125} \mathrm{I}$-rhNGF was used within $6 \mathrm{~d}$ because decreases in displaceable ${ }^{125} \mathrm{I}$-rhNGF binding were noted after this time.

The biological activity of 2- and 3-week-old labeled rhNGF was established with the PC12 assay (Greene and Ruckenstein, 1989), in which ${ }^{125} \mathrm{I}$-rhNGF $(71.6 \mu \mathrm{Ci} / \mu \mathrm{g} ; 1850 \mathrm{Ci} / \mathrm{mmol}$ rhNGF dimer $)$ stimulated neurite outgrowth with an $\mathrm{EC}_{s_{0}}$ of $49 \pm 19 \mathrm{pg} / \mathrm{ml}(n=4 ; 2$-week-old tracer) and $49 \pm 0.8 \mathrm{pg} / \mathrm{ml}(n=3 ; 3$-week-old tracer). Without a biochemical

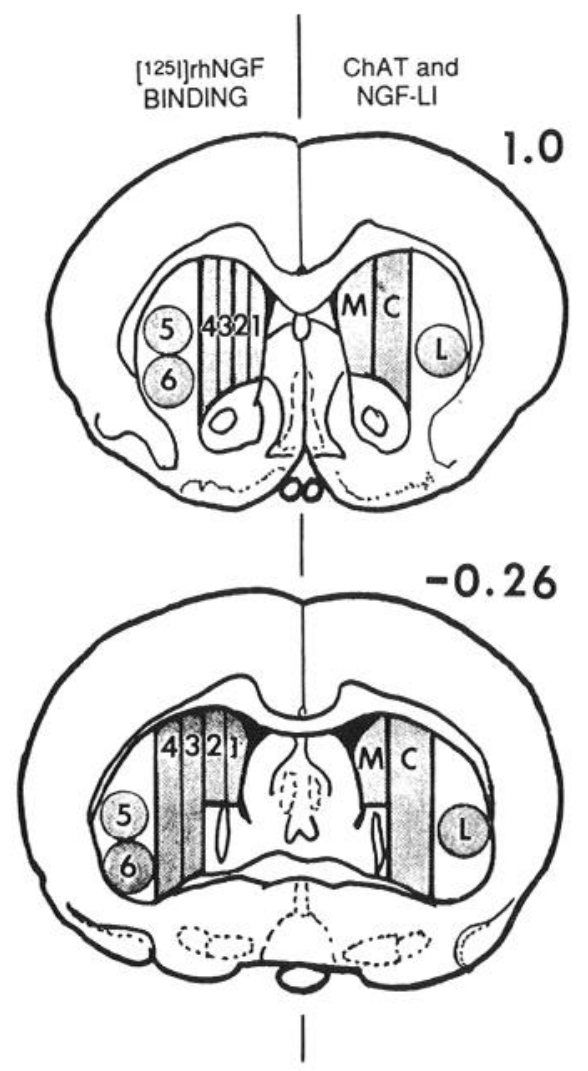

Figure 1. Rostral-caudal extent of neostriatal tissue used for the measure of NGF receptor, ChAT, and NGF-LI. Each marker was measured in both hemispheres, but sampling locations for each are represented unilaterally. Numbers at the top right of each section are the $\mathrm{mm}$ anterior to the bregma suture (Paxinos and Watson, 1982). Left hemisphere, Distribution of 6 subregions of striatum in which ${ }^{125} \mathrm{I}-\mathrm{rhNGF}$ binding autoradiography was measured bilaterally by image analysis. Right hemisphere, Tissues were removed bilaterally from the lateral $(L)$, central $(C)$, or medial $(M)$ striatum for ChAT and NGF-LI measurements.

separation of labeled and unlabeled species, we cannot exclude the possibility that biological activity is due to unlabeled rhNGF. However, the high specific activity of ${ }^{125} \mathrm{I}-\mathrm{rhNGF}$ and the demonstration in the rat brain of retrograde transport of ${ }^{125}$ I-rhNGF that can be blocked by rhNGF (Altar and Bakhit, 1991) also indicate that iodinated rhNGF is biologically active.

${ }^{125}$ I-rhNGF binding assay. Binding assays were conducted according to the procedure of Richardson et al. (1986), with few modifications (Altar et al., 1991). Each section was prewashed for $3 \mathrm{hr}$ at $22^{\circ} \mathrm{C}$ in $100 \mathrm{~mm}$ phosphate-buffered saline ( $\mathrm{pH}, 7.4)$ containing $0.5 \mathrm{~mm} \mathrm{MgCl}$, $1 \mathrm{mg} / \mathrm{ml}$ cytochrome C, $4 \mu \mathrm{g} / \mathrm{ml}$ leupeptin, $0.5 \mathrm{~mm}$ PMSF (BRL, Gaithersburg, MD; first dissolved to $0.1 \mathrm{mg} / \mathrm{ml}$ isopropyl alcohol), and then for an additional $3 \mathrm{hr}$ in the same buffer with $110 \mathrm{pm}{ }^{125} \mathrm{I}-\mathrm{rhNGF}$. This concentration, and concentrations of all radioligands used in this study, is 2-3 times the $K_{d}$ for ${ }^{125} \mathrm{I}$-rhNGF binding to the high-affinity site and thus will label about $90 \%$ of displaceable binding sites. Slides containing adjacent brain sections were incubated in the same solutions with the addition of $100 \mathrm{~nm}$ rhNGF to define nondisplaceable binding. Thereafter, the sections were washed 3 times for $1 \mathrm{~min}$ or for $2 \mathrm{hr}$ in buffer at $22^{\circ} \mathrm{C}$. Sections were fixed for $10 \mathrm{~min}$ in $4 \%$ paraformaldehyde at $22^{\circ} \mathrm{C}$, rinsed for $2 \mathrm{sec}$ in water, and dried within $5 \mathrm{~min}$ by a stream of roomtemperature air.

${ }^{3} \mathrm{H}$-PK 11195 binding assay. ${ }^{3} \mathrm{H}-\mathrm{PK} 11195$, a high-affinity antagonist ligand for the mitochondrial benzodiazepine binding site (MBBS), was used to label gliosis in brain sections (Benavides et al., 1987; Altar and Baudry, 1990) from animals injected with quinolinic acid. Sections 12 $\mu \mathrm{m}$ thick were thawed and incubated for $45 \mathrm{~min}$ at room temperature in a $50 \mathrm{~mm}$ Tris- $\mathrm{HCl}$ buffer $(\mathrm{pH}, 7.4)$ that included $120 \mathrm{~mm} \mathrm{NaCl}$ and $3 \mathrm{~nm}{ }^{3} \mathrm{H}$-PK 11195 (specific activity, $80 \mathrm{Ci} / \mathrm{mmol}$; DuPont-New England Nuclear; Benavides et al., 1987). Ten micromolar Ro 5-4864 


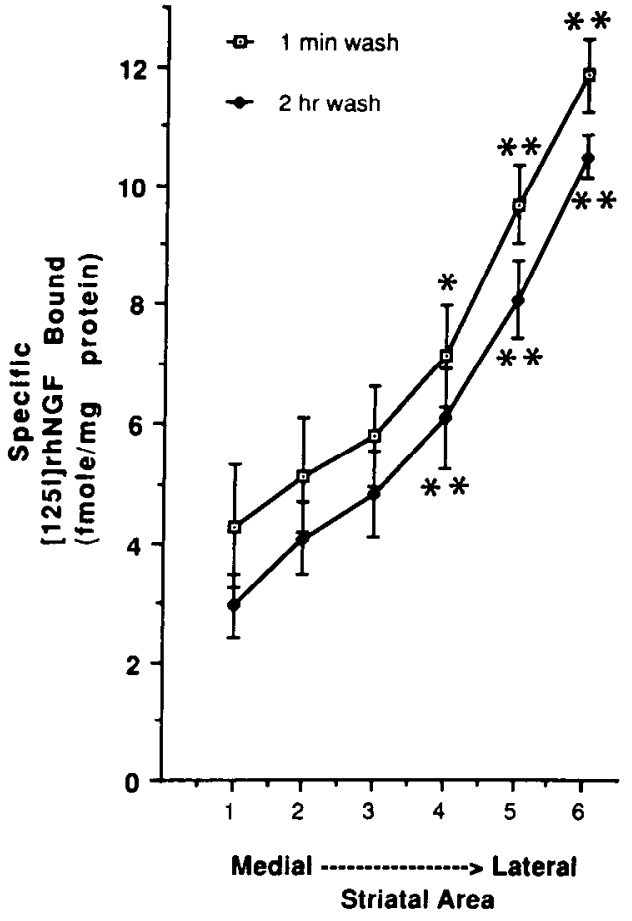

Figure 2. Displaceable ${ }^{125}$ I-rhNGF bound to the 6 subregions of the neostriatum illustrated in Figure 1 in sections washed in unlabeled buffer for $1 \mathrm{~min}$ or $2 \mathrm{hr}$. Values are means \pm SEM for 5 brains. ${ }^{*}, p<0.05$; **, $p<0.01$ versus medial striatum (region 1; Dunnett's $t$ test; $\{6,25$ df ) in the 1-min and 2-hr wash groups.

(Schoemaker et al., 1982; provided by Hoffman-LaRoche, Nutley, NJ) is a potent and selective MBBS agonist that differs structurally from PK 11195 and was used with adjacent sections to define nondisplaceable binding. Sections were washed for $2 \times 1 \mathrm{~min}$ at $4^{\circ} \mathrm{C}$ in the buffer, rinsed $3 \times 1 \mathrm{sec}$ in distilled water, and dried within $5 \mathrm{~min}$.

${ }^{3} \mathrm{H}$-mazindol autoradiography. The density of dopamine nerve terminals in the neostriatum was measured with a modification of the ${ }^{3} \mathrm{H}$ mazindol autoradiography procedure of Javitch et al. (1984). Sections were preincubated in binding buffer $\left(50 \mathrm{~mm}\right.$ Tris, $\mathrm{pH}=7.9$ at $4^{\circ} \mathrm{C}, 120$ $\mathrm{mm} \mathrm{NaCl}$, and $5 \mathrm{~mm} \mathrm{KCl}$ ) for $5 \mathrm{~min}$ at $4^{\circ} \mathrm{C}$ and incubated for $40 \mathrm{~min}$ at $4^{\circ} \mathrm{C}$ in $60 \mathrm{~nm}{ }^{3} \mathrm{H}$-mazindol (DuPont-New England Nuclcar Rescarch Products, Arlington Heights, VA). Nomifensine $(100 \mu \mathrm{M})$ was used to define nondisplaceable binding. The sections were washed twice for 1 min in buffer at $4^{\circ} \mathrm{C}$, once for $5 \mathrm{sec}$ in water, and dried within $5 \mathrm{~min}$.

The labeled sections and ${ }^{3} \mathrm{H}$ - or ${ }^{125} \mathrm{I}$-containing radioactivity standards (Amersham, Inc.) were exposed at room temperature for 2 weeks $\left({ }^{3} \mathrm{H}\right.$ mazindol), 4 weeks ( ${ }^{3} \mathrm{H}$-PK 11195$)$, or $5 \mathrm{~d}\left({ }^{125} \mathrm{I}\right.$-rhNGF) to film sensitive to $\beta$-emissions (Hyperfilm, Amersham, Inc.).

Image analysis. The autoradiographic films were developed in D-19 ( $3 \mathrm{~min}$ ) and fixer $(5 \mathrm{~min})$, with an in-between 30 -sec wash in stop solution (all reagents from Kodak). The developed films were imaged with an RAS 3000 image analysis system (Amersham, Inc., Arlington Heights, VA) according to the regional pattern illustrated in the left hemispheres of Figure 1. The amounts of binding for each ligand were quantificd, and images of total, rhNGF-displaceable, and displaceable binding were produced with computer-assisted image analysis (Altar et al., 1984). The displaceable binding of ${ }^{125}$ I-rhNGF was averaged between the 1-min and the 2-hr washes, and these data were averaged for regions 1 and 2 (medial), 3 and 4 (central), and 5 and 6 (lateral) shown in Figure 1 to compare with the regions in which ChAT was measured by dissection.

$N G F$-like immunoreactivity ( $N G F-L I)$ and ChAT activity. Tissue samples were homogenized according to the procedure of Korsching and Thoenen (1983) with the addition of $0.5 \%$ BSA and $0.1 \%$ gelatin to the homogenization buffer. Microtiter plate wells (Maxisorb, Nunc, Kamstrup, Denmark) were coated with $100 \mu 1$ of protein A-purified rabbit anti-rhNGF (Bennett et al., 1990). The plate bottoms were coated with $10 \mu \mathrm{g} / \mathrm{ml}$ of antibody in coating buffer $\left(0.05 \mathrm{M} \mathrm{Na}_{2} \mathrm{CO}_{3}, \mathrm{pH} 9.6\right)$ for 18 $\mathrm{hr}$ at $4^{\circ} \mathrm{C}$. Excess antibody was removed, and the nondisplaceable bind-

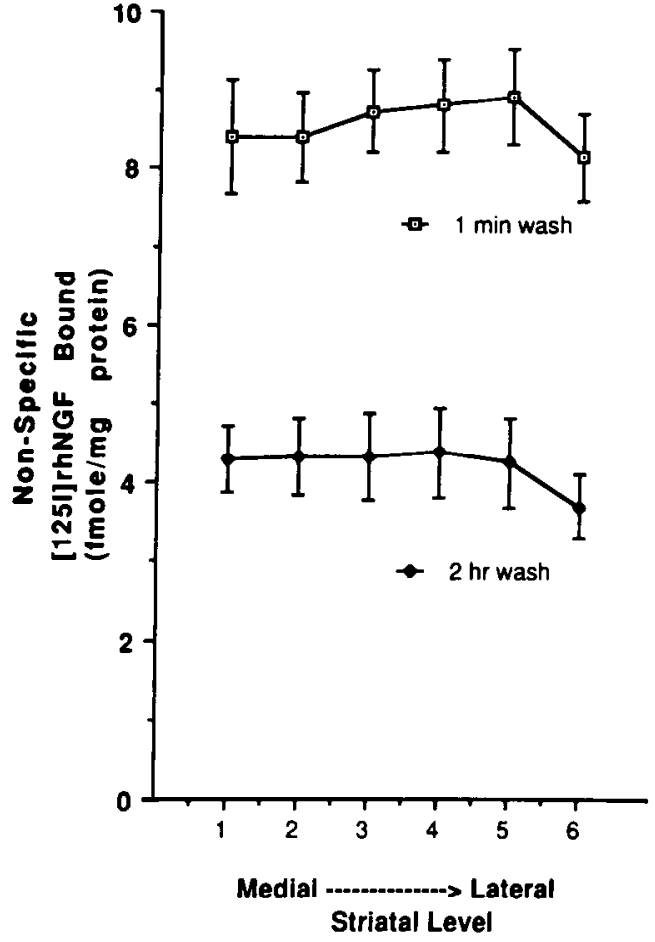

Figure 3. Nondisplaceable ${ }^{125} \mathrm{I}-\mathrm{rhNGF}$ bound to 6 subregions of the neostriatum in the presence of $100 \mathrm{~nm}$ unlabeled rhNGF. The sections used for this figure were the same as those used to define nondisplaceable binding in Figure 2. No regional differences in nondisplaceable binding were obtained with either wash condition.

ing sites were blocked by the addition of $150 \mu l$ per well of PBS containing $5 \mathrm{gm} /$ liter of BSA and thimerosal (blocking buffer), followed by incubation at room temperature for $1-2 \mathrm{hr}$.

After washing the wells with buffer (PBS containing $0.5 \mathrm{ml} / \mathrm{liter}$ of Tween-20 and $0.1 \mathrm{ml} /$ liter of thimerosal), standards (rhNGF) and samples diluted in PBS containing $5 \mathrm{gm} /$ liter of BSA, $0.5 \mathrm{ml} /$ liter of Tween20 , and $0.1 \mathrm{ml} /$ liter of thimerosal (assay diluent) were added to the wells in $100-\mu \mathrm{l}$ volumes and incubated for $2 \mathrm{hr}$ at room temperature. The wells were washed in buffer, and 100- $\mu$ l aliquots of horseradish peroxidase-labeled rabbit anti-rhNGF were added to each well. After a 2-hr incubation at room tempcrature, the plates were washed as above and incubated for $20 \mathrm{~min}$ with $100 \mu \mathrm{l}$ of orthophenylene diamine (Sigma, St. Louis, MO) at $2.2 \mathrm{mmol} /$ liter in PBS (pH, 7.2) with $0.012 \%(\mathrm{v} / \mathrm{v})$ hydrogen peroxide. The formation of color was stopped with $100 \mu \mathrm{l} /$ well of $2.25 \mathrm{~m}$ sulfuric acid, and the absorbance was read at $490 \mathrm{~nm}$ minus $405-\mathrm{nm}$ background. The data were reduced using a 4-parameter curve-fitting program developed at Genentech, Inc., based on an algorithm for least-squares estimation of nonlinear parameters.

The activity of choline acetyltransferase (ChAT) was measured by the Fonnum procedure (Fonnum, 1981) with $10 \mathrm{~mm}$ EDTA sodium salt and $0.2 \%(\mathrm{v} / \mathrm{v})$ Triton $\mathrm{X}-100$ added to the homogenization solution. Fach dissected neostriatum was homogenized in $20 \mathrm{vol} 0.32 \mathrm{~m}$ sucrose. Two- and 4- $\mu$ l aliquots were used to measure protein content (Lowry) and ChAT activity, respectively. The sensitivity of the ChAT assay was $0.12 \mathrm{nmol}$ ACh formed from the acctylation of choline by ChAT in the presence of ${ }^{3} \mathrm{H}$-acetyl coenzyme $\mathrm{A}$, as determined with $\mathrm{ChAT}$ extracted from bovine brain (Sigma).

Data analysis. Statistical analysis was accomplished with Student's $t$ test (paired comparisons) or Dunnett's $t$ test (multiple comparisons) following a 1-way analysis of variance.

\section{Results}

${ }^{125}$ I-rhNGF binding in rat and rabbit

Considerable amounts of ${ }^{125}$ I-rhNGF were bound throughout the neostriatum of either species. In the rat, the percent of total ${ }^{125}$ I-rhNGF binding that was displaced by $100 \mathrm{~nm}$ rhNGF after 

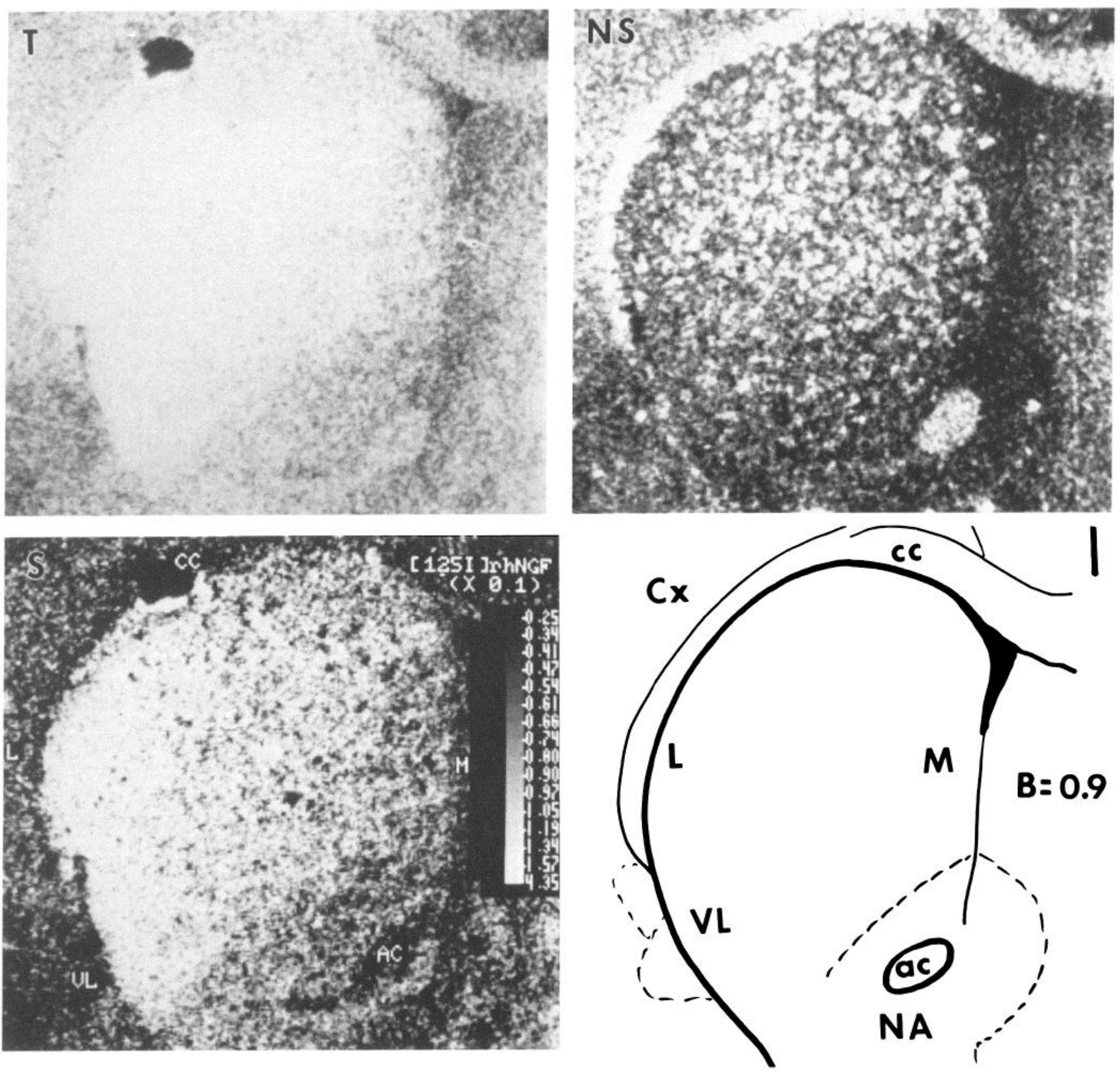

Figure 4. Total $(T)$, nonspecific $(N S)$, and specific $(S){ }^{125} \mathrm{I}-\mathrm{rhNGF}$ binding in the rat neostriatum at a representative coronal section $0.9 \mathrm{~mm}$ rostral to bregma (2-hr wash condition). A 110-pM concentration of ${ }^{125} \mathrm{I}-\mathrm{rhNGF}$ was used to define total binding, and a coincubation with $100 \mathrm{~nm}$ rhNGF defined nondisplaceable binding. The computer-generated image of displaceable binding was produced by digital subtraction of superimposed total and nondisplaceable binding images. The illustration on the bottom right shows prominent anatomical landmarks at this coronal brain level. The gray scale relates image gray value to $0.1 \times$ fmol ${ }^{125} \mathrm{I}-\mathrm{rhNGF}$ bound per mg protein. $a c$, anterior commissure; $B$, mm rostral to the bregma suture; $c c$, corpus callosum; $C x$, neocortex; $L$, lateral caudate-putamen; $M$, medial caudate-putamen; $N A$, nucleus accumbens; $V L$, ventrolateral caudateputamen.

$1 \mathrm{~min}$ or $2 \mathrm{hr}$ of washing in radioligand-free buffer was, respectively, $60 \pm 2 \%$ and $74 \pm 3 \%$ in the most lateral caudateputamen and $32 \pm 7 \%$ and $40 \pm 7 \%$ in the most medial caudateputamen $(p<0.001$ between lateral and medial caudate-putamen for both wash conditions). These differences were due to variations in displaceable binding (Fig. 2) and not nondisplaceable ${ }^{125}$ I-rhNGF binding (Fig. 3), which was uniform throughout the neostriatum (see also Fig. 4). Two nanomolar rhNGF displaced about $80 \%$ as much ${ }^{125}$ I-rhNGF binding as $100 \mathrm{~nm}$ rhNGF. Thus, the $100 \mathrm{~nm}$ concentration was routinely used to define displaceable binding, as reported (Richardson et al., 1986; Raivich and Kreutzberg, 1987; Riopelle et al., 1987; Bernd et al., 1988).

Consistent with ${ }^{125}$ I-rhNGF binding to a high-affinity site, the amount of displaceable ${ }^{125} \mathrm{I}-\mathrm{rhNGF}$ binding decreased only slightly following $2 \mathrm{hr}$ of wash at $22^{\circ} \mathrm{C}$ in unlabeled buffer compared with a 1-min wash (Fig. 3). Displaceable binding increased from the medial to the lateral striatum following postincubation washes of $1 \min (F\{5,24\}=12.2 ; p<0.001)$ or $2 \mathrm{hr}(F\{5,24\}$ $=19.4 ; p<0.001$; Fig. 3). For example, in the 2-hr group, 
Figure 5. Total and nonspecific ${ }^{125} \mathrm{I}-$ rhNGF binding at 2 levels of the rabbit neostriatum under conditions identical to those used in Figure 4. Note that binding is not displaced by unlabeled rhNGF in the corpus callosum, anterior commissure, and optic nerve (top) and optic chiasm (bottom).
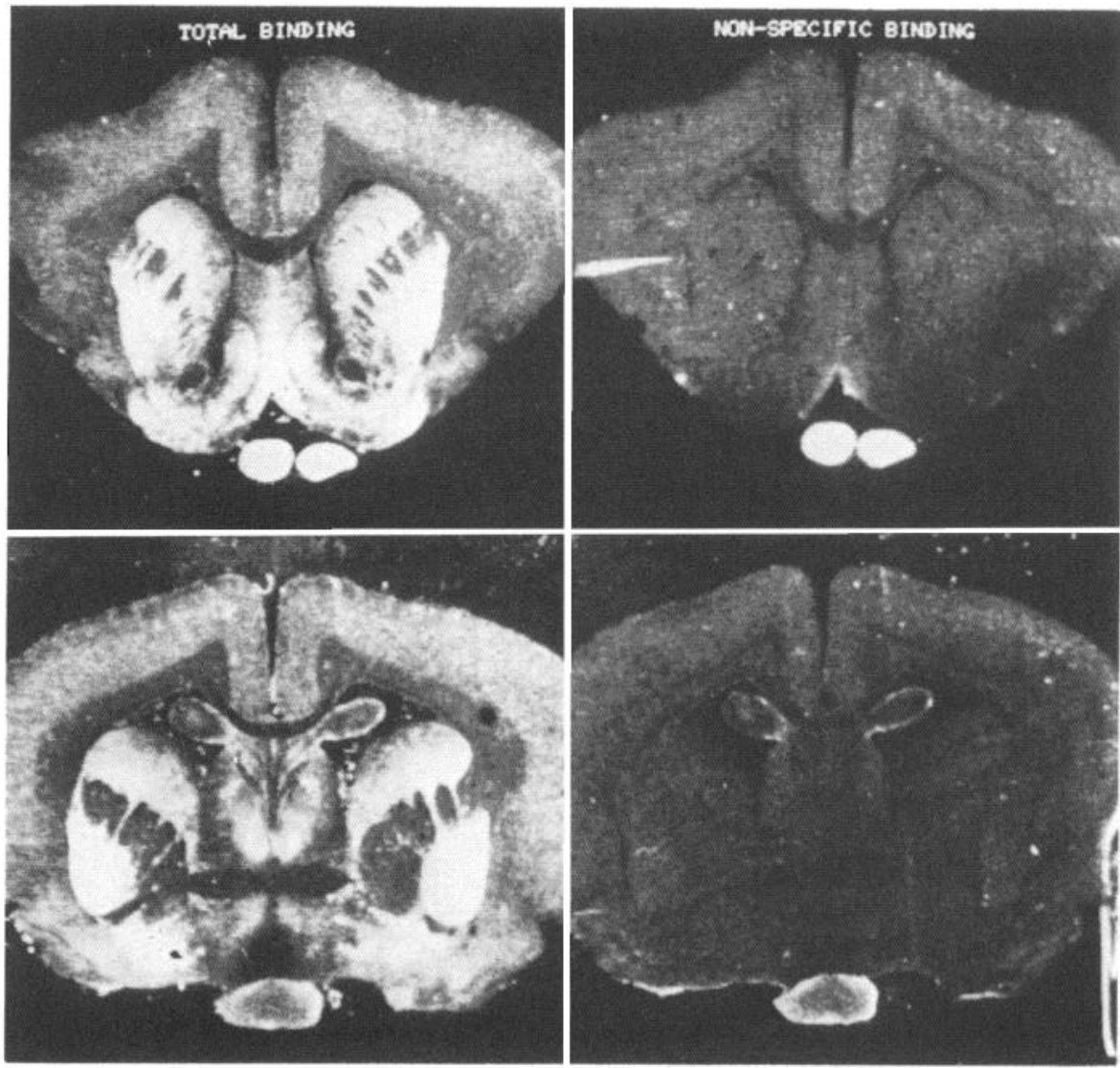

displaceable ${ }^{125} \mathrm{I}-\mathrm{rhNGF}$ binding in the medial striatum was 2.95 $\pm 0.5 \mathrm{fmol} / \mathrm{mg}$ protein. This increased by about 3 -fold to a maximum of $10.5 \pm 0.4 \mathrm{fmol} / \mathrm{mg}$ protein in the ventrolateral striatum. Digitized autoradiographs of total, nondisplaceable, and displaceable ${ }^{125} \mathrm{I}$-rhNGF binding to representative neostriatal sections (2-hr wash) revealed the typical pattern of NGF binding in the rat (Fig. 4) and rabbit (Fig. 5). The gradient in total binding of the rat neostriatum was more readily apparent after subtraction of the uniform nondisplaceable binding image from the total binding image. The image of displaceable ${ }^{125} \mathrm{I}-$ rhNGF binding most clearly revealed the receptor gradient, with the highest density of NGF receptors present in the lateral and ventrolateral striatum. In the rabbit, the separation of the caudate nucleus from the putamen by the fibers of the internal capsule clearly revealed the greater density of ${ }^{125}$ I-rhNGF binding in the putamen and, within the caudate nucleus, the greater density of sites in the ventrolateral than in the dorsomedial portion (Fig. 5). Quantitation showed a 2.5-fold-greater density of displaceable sites in the rabbit putamen than in the caudate (data not shown).

\section{ChAT activity and NGF-LI in the intact neostriatum}

Increasing amounts of ChAT activity were measured from the medial to lateral portions of the neostriatum (Fig. 6). The 2.4fold increase in ChAT activity from the medial to lateral neostriatum was highly significant $(F\{2,8\}=18.9 ; p<0.001)$, with lateral activities exceeding those found centrally or medially $(p<0.01)$. The average amounts of ${ }^{125} \mathrm{I}-\mathrm{rhNGF}$ binding and ChAT activity in the medial, central, and lateral areas were positively correlated $(r=+0.99 ; p<0.001)$. NGF-LI was also prevalent in the neostriatum but, in contrast to ChAT and ${ }^{125} \mathrm{I}-$ rhNGF binding, was evenly distributed along the medial-lateral dimension (Fig. 6).

\section{Effects of striatal quinolinic acid or 6-hydroxydopamine}

Basal levels of displaceable binding of the glial marker, ${ }^{3} \mathrm{H}-\mathrm{PK}$ 11195 , were uniformly distributed in the caudate-putamen (Fig. 7) and exceeded by 2 -fold the level of background binding defined with Ro 5-4864. Intrastriatal injections of quinolinic acid elevated ${ }^{3} \mathrm{H}$-PK 11195 binding by $6-8$-fold in the lateral, central, and medial caudate-putamen. In contrast, these lesions lowered displaceable NGF binding by $21 \%, 33 \%$, and $43 \%$ in the lateral, central, and medial caudate-putamen, respectively (Fig. 8). The ${ }^{125} \mathrm{I}$-rhNGF binding in the entire cross-sectional area of the striatum and ChAT activity in homogenates of the dissected caudateputamen were each decreased by $40 \%$ following quinolinic acid (Fig. 8).

Injections of 6-hydroxydopamine produced $70 \%$ and $77 \%$ ( $p$ $<0.01$, Student's $t$ test) depletions of dopamine nerve terminal densities determined with ${ }^{3} \mathrm{H}$-mazindol but not displaceable ${ }^{125} \mathrm{I}$ rhNGF binding at 1 and 4 weeks after the injection (Table 1).

\section{Discussion}

The present study has revealed that high-affinity binding sites for ${ }^{125} \mathrm{I}-\mathrm{rhNGF}$ in the caudate-putamen of the rat and rabbit are dense and distributed with a 2-3-fold increasing medial-to-lateral gradient. With the present methods, neostriatal binding sites for ${ }^{125}$ I-rhNGF were found to be among the most dense in the brain, second only to the interpeduncular nucleus and spinal trigeminal tract (Altar et al., 1991). It is thus surprising that 


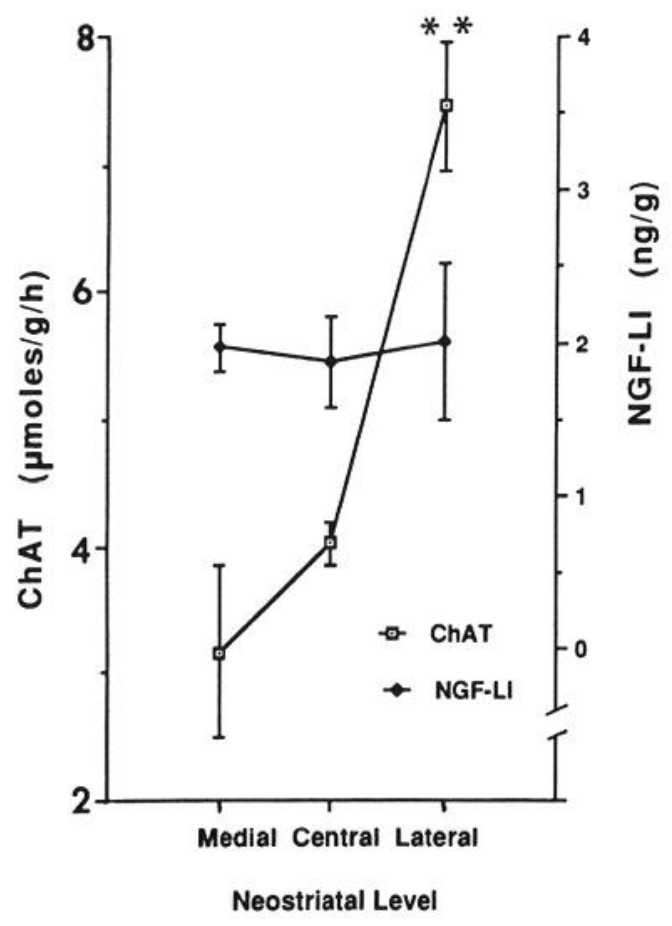

Figure 6. ChAT activity (left ordinate) and NGF-LI (right ordinate) in the 3 neostriatal subregions illustrated in the left half of Figure 1. $=4-5$ determinations, with tissues from 4-5 animals used per determination. ${ }^{* *}$, significance level of $p<0.01(3,13 \mathrm{df})$ versus ChAT activity in the medial and central caudate-putamen. Vertical lines represent SEM.

previous studies have been equivocal as to the presence of NGF binding sites in the caudate-putamen of the human or rat. In large part, this has probably been due to the lack of selective high-affinity binding by the monoclonal antibodies and incomplete saturation of high-affinity sites by ${ }^{125}$ I-muNGF. The 192monoclonal antibody (MAb) IgG directed against the mouse NGF receptor labels the low-affinity site in Schwann cells and PC12 cells (Chandler et al., 1984; DiStefano and Johnson, 1988) as well as high-affinity sites in PC12 cells (Chandler et al., 1984). Because the high- and low-affinity NGF receptors are encoded by a single gene, the MAb probably recognizes a common epitope on these interconverting or posttranslationally modified receptors. Even so, NGF receptors either have not been found in the human caudate or putamen with the MAb 82.11 (Hefti and Mash, 1989) or were shown with the MAb 192 to bind only

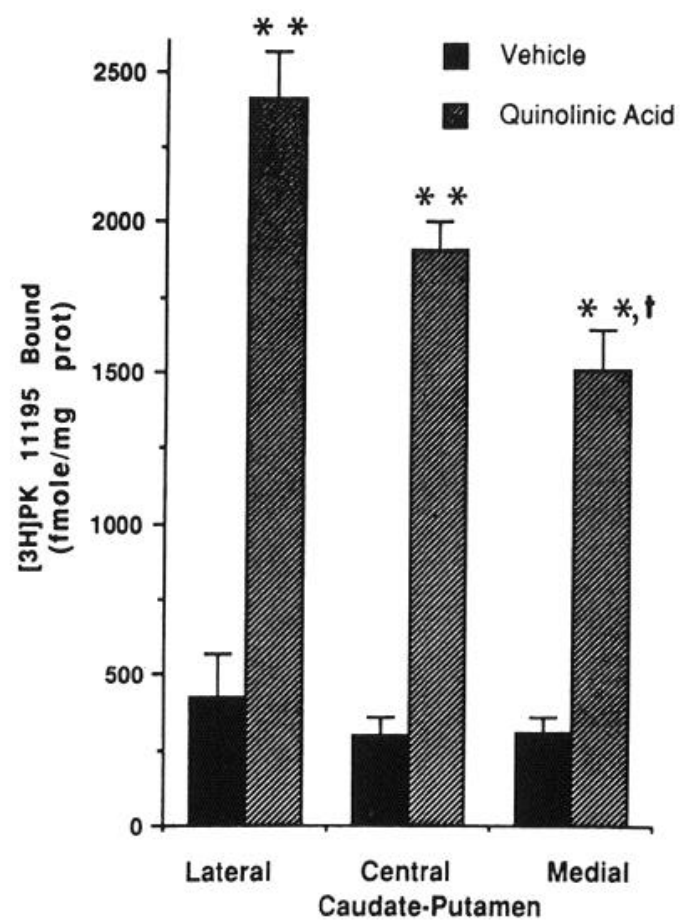

Figure 7. Increased density of the peripheral benzodiazepine-bindingsite ligand ${ }^{3} \mathrm{H}-\mathrm{PK} 111951$ week following an intrastriatal injection of $150 \mathrm{nmol}$ quinolinic acid. Values are means $\pm \mathrm{SEM} ; n=5$ rats per group. Displaceable binding was elevated $6-8$-fold in each caudateputamen subregion. ${ }^{* *}, p<0.01 ; \dagger, p<0.05$ versus binding in the lateral caudate-putamen of quinolinic acid-treated rats.

in the ventrolateral monkey putamen (Kordower et al., 1988; Schatteman et al., 1988). NGF-receptor antibodies also fail to label NGF receptors in the rat neostriatum in some studies (Batchelor et al., 1988; Gage et al., 1989) or identify only sparse, scattered receptors (Gibbs et al., 1989; Kiss and Patel, 1989; Woolf et al., 1989). However, in agreement with our findings, NGF receptors have been colocalized with ChAT (Kordower et al., 1988; Kiss and Patel, 1989; Woolf et al., 1989) and are found in lower density in medial striatum (Pioro and Cuello, 1990).

Interpretations of the high-affinity nature of direct NGF ligand-binding studies are less equivocal, because ${ }^{125} \mathrm{I}$-rhNGF concentrations, wash, and other conditions have been shown to optimize high-affinity binding and minimize or eliminate lowaffinity binding. Nevertheless, prior radioligand studies of the

Table 1. ${ }^{3} \mathrm{H}$-mazindol and ${ }^{125}$ I-rhNGF binding in the caudate-putamen after local infusion of 6-hydroxydopamine

\begin{tabular}{|c|c|c|c|c|c|c|}
\hline \multirow[b]{3}{*}{$\begin{array}{l}\text { Time after } \\
\text { infusion }\end{array}$} & \multicolumn{6}{|c|}{ Displaceable ligand bound (fmol/mg protein) } \\
\hline & \multicolumn{3}{|c|}{${ }^{3} \mathrm{H}$-mazindol } & \multicolumn{3}{|l|}{${ }^{125} \mathrm{I}$-rhNGF } \\
\hline & Intact & Lesion & $\begin{array}{l}\text { \% } \\
\text { Decrease }\end{array}$ & Intact & Lesion & $\begin{array}{l}\% \\
\text { Decrease } \\
\end{array}$ \\
\hline 1 week & $41 \pm 2.6$ & $9.2 \pm 2.6^{* *}$ & 77 & $8.7 \pm 0.5$ & $9.8 \pm 0.9$ & - \\
\hline 4 weeks & $58 \pm 2.4$ & $18 \pm 4.7^{* *}$ & 70 & $10.4 \pm 0.7$ & $9.8 \pm 0.8$ & - \\
\hline
\end{tabular}

Six male Sprague-Dawley rats received an infusion into the central neostriatum of the vehicle (Intact) or 6-hydroxydopamine (Lesion) as described in Materials and Methods. The density of dopamine nerve terminals $\left({ }^{3} \mathrm{H}\right.$-mazindol binding) and NGF binding sites was measured in adjacent sections with saturating concentrations of each radioligand with appropriate unlabeled compounds to define nondisplaceable binding.

$* *, p<0.01$ versus intact neostriatum, paired $t$ test. 


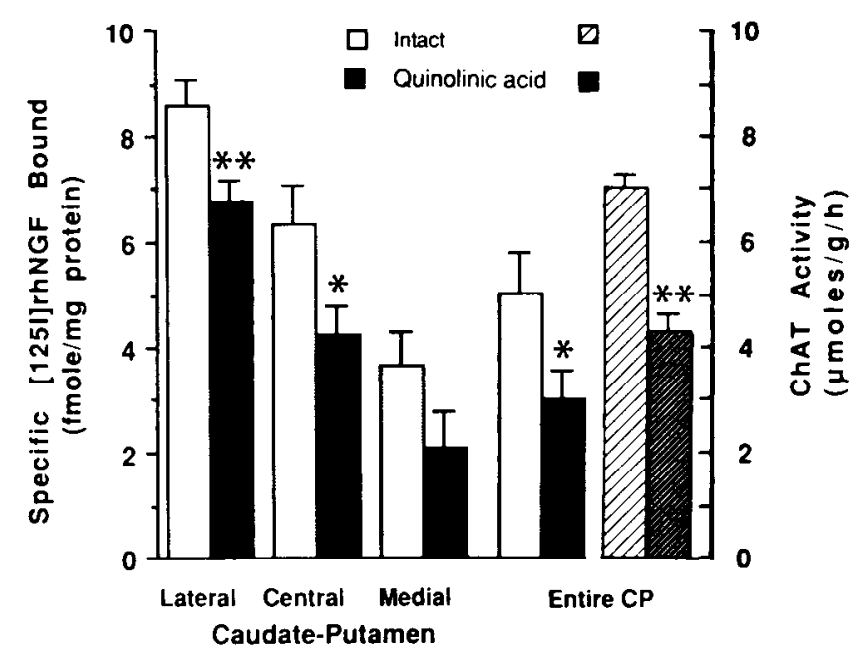

Figure 8. Similar decreases in displaceable ${ }^{125} \mathrm{I}-\mathrm{rhNGF}$ binding (left ordinate) and ChAT activity (right ordinate) in the lateral, medial, or entire caudate-putamen 1 week following an intrastriatal injection of $150 \mathrm{nmol}$ quinolinic acid. ${ }^{*}, p<0.05 ;{ }^{* *}, p<0.02$ versus hemisphere injected with vehicle in other rats; paired $t$ test. Vertical lines represent SEM.

high-affinity NGF receptor with ${ }^{125}$ I-labeled muNGF (Richardson et al., 1986; Raivich and Kreutzberg, 1987; Riopelle et al., 1987; Mobley et al., 1989) have found no binding or low and uniform binding throughout the rat caudate-putamen.

The present use of dry-film autoradiography, iodination of rhNGF to very high specific activity, quantitative image analysis and enhancement that can easily detect a 2 -fold difference in receptor number, and the exclusion of postbinding organic solvent washes and liquid film emulsions are all likely to have contributed to the more sensitive detection of high-affinity binding than obtained with emulsion autoradiography. Indeed, the techniques used here also afford visualization of high-affinity NGF sites in neocortical and hippocampal areas (Altar et al., 1991) that are undetected with ${ }^{125}$ I-muNGF emulsion autoradiography (Richardson et al., 1986; Raivich and Kreulzberg, 1987). The sparse and uniform neostriatal pattern observed with ${ }^{125} \mathrm{I}$-muNGF and the lack of binding in cholinergic terminal areas like the cortex and hippocampus indicate that a loss of label from neuropil may occur with the emulsion technique. In support of this conclusion, Burke and Karanas (1990) showed that the processes of ChAT-positive neurons are greater in the lateral than in the medial rat caudate-putamen, while ChATpositive cell bodies are evenly distributed in this region. Thus, the medial-lateral gradient of ${ }^{125}$ I-rhNGF binding sites may result from the presence of these high-affinity sites on cholinergic neuropil and cell bodies.

The medial-lateral gradient in specific binding sites for thNGF was not due to medial-lateral variations in nonspecific binding (Fig. 3) or to an artifact due to a medial-lateral variation of NGF protein. Nonspecific binding and NGF-LI were each uniformly concentrated throughout the medial-lateral extent of the caudate putamen. Also, tissue section washes for up to $24 \mathrm{hr}$, which dislodge virtually all bound ${ }^{125}$ I-rhNGF from its specific binding site (Altar et al., 1991), do not alter the gradient produced by subsequent 3-hr incubations with ${ }^{125}$ I-rhNGF (M. DugichDjordjevic and C. A. Altar, unpublished observations). The medial-lateral gradient can instead be explained by the orga- nization of intrinsic NGF-receptor-containing ncostriatal clements in a medial-lateral manner. The distribution of cholinergic markers, including high-affinity ${ }^{3} \mathrm{H}$-choline uptake (Rea and Simon, 1981) and the density of the ACh transporter ligand ${ }^{3} \mathrm{H}$-vesamicol (Marien et al., 1987) are organized in a quantitatively similar 2-3-fold medial-lateral gradient. Also, ${ }^{125} \mathrm{I}-\mathrm{rhNGF}$ binding was positively correlated with the distribution of the cholinergic neuron marker, ChAT, and each was decreased to an equal extent by intrastriatal quinolinic acid. These findings make it most plausible that the high-affinity NGF sites observed throughout the striatum are on cholinergic neurons, and not only in the ventrolateral caudate-putamen (Riopelle et al., 1987). The absence of NGF binding sites on dopamine nerve terminals was shown by the failure of ${ }^{125}$ I-rhNGF binding to be altered by $70-77 \%$ losses of these terminals following 6-hydroxydopamine. The absence of high-affinity NGF binding sites on dopaminergic nerve terminals is consistent with the lack of a trophic role of NGF for mesencephalic dopamine neurons (Hefti et al., 1989). These findings also suggest that dopamine depletions in the striatum did not elicit an up- or downregulation of NGF receptor number, because the near-saturating concentrations of ${ }^{125}$ I-rhNGF used would reveal a change in rhNGFbinding-site number.

Excitotoxic lesions of the striatum with quinolinic acid promoted gliosis in this region. The increase in glial cells, but not mitochondrial markers such as cytochrome oxidase, are labeled by peripheral-type benzodiazepine-binding-site ligands, including ${ }^{3}$ H-PK 11195 (Schoemaker et al., 1982; Dubois et al., 1988). The 6-8-fold increases in glial binding sites for ${ }^{3} \mathrm{H}-\mathrm{PK} 11195$ and $40 \%$ decrease in ${ }^{125}$ I-rhNGF binding show that NGF receptors labeled here are probably not on glial cells. Glia are believed to contain the low-affinity form of the NGF receptor (Springer, 1988). Glia are also believed to produce NGF, and gliosis following intrastriatal infusions of quinolinic acid produces a large increase in NGF-LI (C. Bakhit, unpublished observations). Thus, the loss of high-affinity NGF binding sites is probably not due to a downregulation of NGF receptors secondary to decreases in NGF. Instead, these high-affinity sites are probably lost because they are on cholinergic interneurons destroyed by quinolinic acid (Schwarcz et al., 1983). The loss of NGF sites following quinol:nic acid predicts that decreases in NGF receptor levels will be found in the caudate nucleus and putamen of patients with Huntington's chorea (Nagai et al., 1983), Alzheimer's disease (Oyangai et al., 1989), or progressive supranuclear palsy (Oyangai et al., 1989), because neostriatal cholinergic interneurons are lost in these disorders.

In contrast to the medial-to-lateral gradient for NGF binding sites, NGF-LI in the striatum was of equal concentration along this dimension. The equal density of NGF-LI through the medial-to-lateral extent of the neostriatum indicates that the source(s) of NGF-LI in the intact neostriatum may be cells that receive a cholinergic input and whose neostriatal distribution is also uniform. One neuronal candidate for these criteria is the striatal GABAergic interneurons. Their ability to produce, store, and release NGF is, however, unknown. Glial cells are also uniformly distributed throughout the intact striatum (see Fig. 7; Benavides et al., 1987) and are other likely sources for NGF.

Because NGF-LI is uniformly distributed in the neostriatum, the heterogeneous content of NGF receptors in the caudateputamen may dictate preferential effects for NGF in the lateral and ventrolateral portions of this structure. An analogous situation exists for striatal $\mathrm{D}_{2}$ dopamine receptors. They are also 
2-3-fold more concentrated in the lateral caudate-putamen (Altar et al., 1984), yet dopamine is uniformly distributed in this structure (Ternaux et al., 1977). Exogenously applied dopamine receptor antagonists increase dopamine metabolism and release to a greater extent in the lateral than in the medial rat striatum (Childs and Gale, 1986; Yamamoto and Pehek, 1990). The presence of regional gradients in NGF receptors in the brain, including the nucleus accumbens (Altar et al., 1991) and striatum, may predict regions where responses to NGF may be the greatest, such as following rhNGF delivery to adult rats via intraventricular (Hagg et al., 1989) or intrastriatal (Gage et al., 1989; Armanini et al., 1990) routes. Exogenously delivered rhNGF may be sequestered in neostriatal subregions in proportion to their receptor density and may prevent or retard the loss of striatal cholinergic neurons in normal aging (McGeer et al., 1971; Strong et al., 1982), Huntington's chorea, or progressive supranuclear palsy (Stccle ct al., 1964; Nagai et al., 1983; Oyangai et al., 1989).

In conclusion, the increasing medial-to-lateral gradient of NGF binding in the intact caudate-putamen, the parallel response of NGF binding with cholinergic neurons but not dopamine neurons or glia, and the uniform distribution of NGF-LI in this region are consistent with a trophic role for NGF in the neostriatum (Mobley et al., 1985, 1989; Aloc, 1987; Hagg et al., 1989). These binding sites for NGF are likely to play a role in the maintenance of striatal cholinergic neurons throughout the neostriatum and not just for sparsely populated ventrolateral sites, as suggested by prior NGF receptor studies. This conclusion is supported by the observation that the intraventricular delivery of antibodies to muNGF, which enter the striatum (Schweitzer, 1989), lowers ChAT levels in this region if the antibodies are neutralizing against NGF (Vantini et al., 1989). Indeed, NGF augments ChAT activity in the medial caudateputamen not only in injured or intact neostriatal cholinergic neurons of neonatal rats (Mobley et al., 1985, 1989; Aloe, 1987), but also in intact (Hagg et al., 1989) or injured adult rats (Gage et al., 1989; Armanini et al., 1990).

\section{References}

Aloe L (1987) Intracerebral pretreatment with nerve growth factor prevents irreversible brain lesions in neonatal rats injected with ibotenic acid. Biotechnology 5:1085-1086.

Altar CA, Bakhit C (1991) Receptor-mediated transport of human recombinant nerve growth factor from olfactory bulb to forebrain cholinergic nuclei. Brain Kes, in press.

Altar CA, Baudry M (1990) Systematic injection of kainic acid: gliosis in olfactory and limbic brain regions quantified with $\left[{ }^{3} \mathrm{H}\right] \mathrm{PK} 11195$ binding autoradiography. Exp Neurol 109:333-341.

Altar CA, Walter RJ, Neve KA, Marshall JF (1984) Computer-assisted video analysis of ${ }^{3} \mathrm{H}$-spiroperidol autoradiography. J Neurosci Meth 10:173-188.

Altar CA, Burton LE, Bennet G, Dugich-Djordjevic M (1991) Recombinant human nerve growth factor is biologically active and labels novel high affinity binding sites in rat brain. Proc Natl Acad Sci USA, in press.

Armanini M, Feinglass S, Bakhit C, Altar CA (1990) Nerve growth factor promotes the recovery of neostriatal choline acetyltransferase following mechanical lesion. Soc Neurosci Abstr 16:478.

Batchelor PE, Armstrong DM, Blaker SN, Gage FH (1988) Nerve growth factor receptor and choline acetyltransferase colocalization in neurons within the rat forebrain: response to fimbria fornix transection. J Comp Neurol 284:187-204.

Benavides J, Fage D, Carter C, Scatton B (1987) Peripheral type of benzodiazepine binding sites are a sensitive indirect index of neuronal damage. Brain Res 421:167-172.

Bennett GL, Burton LE, Chan WP, Wong WLT (1990) Sensitive en- zyme immunoassay for recombinant human NGF. J Cell Biochem [Suppl] 14F:87.

Bernd P, Martinez HJ, Dreyfus CF, Black IB (1988) Localization of high-affinity and low-affinity nerve growth factor receptors in cultured rat basal forebrain. Neuroscience 26:121-129.

Burke RE, Karanas AL (1990) Demonstration of a medial to lateral gradient in the density of cholinergic neuropil in the rat striatum. Neurosci Lett 108:58-64.

Chandler CE, Parsons LM, Hosang M, Shooter EM (1984) A monoclonal antibody modulates the interaction of nerve growth factor with PC1 2 cells. J Biol Chem 259:6882-6889.

Childs JA, Gale K (1986) Mediolateral distribution of dopamine metabolites in rat striatum following chlorpromazine. Soc Neurosci Abstr $12: 872$.

De Larco JE, Preston YA, Todaro GJ (1981) Properties of a sarcomagrowth-factor-like peptide from cells transformed by a temperaturesensitive sarcoma virus. J Cell Physiol 109:143-152.

DiStefano PS, Johnson EM (1988) Nerve growth factor receptors on cultured rat Schwann cells. J Neurosci 8:231-241.

DuBois A, Benavides J, Peny B, Duverger D, Fage D, Gotti B, MacKenzie ET, Scatton B (1988) Imaging of primary and remote ischaemic and excitotoxic brain lesions. Brain Res 445:77-90.

Fonnum $F$ (1981) A rapid radiochemical method for the determination of cholineacetransferase. J Neurochem 24:407-409.

Gage FH, Batchelor P, Chen KS, Chin D, Higgins GA, Koh S, Deputy S, Rosenberg MB, Fischer W, Bjorklund A (1989) NGF receptor reexpression and NGF-mediated cholinergic hypertrophy in the damaged adult neostriatum. Neuron 2:1177-1184.

Gibbs RB, McCabc JT, Buck CR, Chao MV, Pfaff DW (1989) Expression of NGF receptor in the rat forebrain detected with in situ hybridization and immunohistochemistry. Mol Brain Res 6:275-287.

Gomez-Pinilla G, Cotman CW, Nieto-Sampedro M (1989) NGF receptor immunoreactivity in aged rat brain. Brain Res 479:252-262.

Greene LA, Rukenstein A (1989) The quantitative bioassay of nerve growth factor with PCl 2 cells. In: Nerve growth factors (Rush RA, ed), pp 139-149. New York: Wiley.

Guyenet P, Euvrard C, Javoy F, Herbert A, Glowinski J (1977) Regional differences in the sensitivity of cholinergic neurons to dopaminergic drugs and quipazine in the rat striatum. Brain Res 136:487500 .

Hagg T, Hagg F, Vahlsing HL, Manthorpe M, Varon S (1989) Nerve growth factor effects on cholinergic neurons of neostriatum and nucleus accumbens in the adult rat. Neuroscience 30:95-103.

Hefti F, Mash DC (1989) Localization of nerve growth factor receptors in normal human brain and in Alzheimer's disease. Neurobiol Aging $10: 75-85$.

Hefti F, Hartikka J, Salvatierra A, Weiner WJ, Mash DC (1986) Localization of nerve growth factor receptors in cholinergic neurons of the human basal forebrain. Neurosci Lett 69:37-41.

Hefti F, Hartikka J, Knusel B (1989) Function of neurotrophic factors in the adult and aging brain and their possible use in the treatment of neurodegenerative diseases. Neurobiol Aging 10:515-533.

Javitch JA, Blaustein RO, Snyder SH (1984) [ $\left.{ }^{3} \mathrm{H}\right]$ mazindol binding associated with neuronal dopamine and norepinephrine uptake sites. Mol Pharmacol 26:35-44.

Kiss J, Patel A (1989) Characterization of neurons containing nerve growth factor receptors in the rat neostriatum. Neurosci Lett 105 : 251-256.

Kordower JH, Bartus RT, Bothwell M, Schatteman G, Gash DM (1988) Nerve growth factor receptor immunoreactivity in the non-human primate (Cebus apella): distribution, morphology, and colocalization with cholinergic enzymes. J Comp Neurol 277:465-486.

Korsching S, Thoenen H (1983) Quantitative demonstration of the retrograde axonal transport of endogenous nerve growth factor. Neurosci Lett 39:1-4.

Korsching S, Auburger G, Heumann R, Scott J, Thoenen H (1985) Levels of nerve growth factor and its mRNA in the central nervous system of the rat correlate with cholinergic innervation. EMBO J 4: $13890-13903$.

Kuhar MJ, Unnerstall JR (1982) In vitro receptor autoradiography: loss of label during ethanol dehydration and preparative procedures. Brain Res 244:178-181.

Laemmli VK (1970) Cleavage of structural proteins during the assembly of the head of bacteriophage T4. Nature 227:680-685.

Marien MR, Parsons SM, Altar CA (1987) Quantitative autoradiog- 
raphy of brain binding sites for the vesicular acetylcholine transport blocker 2-(4-phenylpiperidino)-cyclohexanol (AH 5183). Proc Natl Acad Sci USA 84:876-880.

McGeer EG, Fibiger HC, McGeer PL, Wickson V (1971) Aging and brain enzymes. Exp Gerontol 6:391-396.

Mobley WC, Rutkowski JL, Tennekoon SJ, Buchanan K, Johnston MV (1985) Choline acetyltransferase in striatum of neonatal rats increased by nerve growth factor. Science 229:284-287.

Mobley WC, Woo JE, Edwards RH, Riopelle RJ, Longo FM, Weskamp GH, Otten W, Valletta JS, Johnston MV (1989) Developmental regulation of nerve growth factor and its receptor in the rat caudateputamen. Neuron 3:655-664.

Nagai T, McGeer PL, Peng JH, McGeer EG, Dolman CE (1983) Choline acetyltransferase immunohistochemistry in brains of Alzheimer's disease patients and controls. Neurosci Lett 36:195-199.

Oyangai K, Takahashi H, Wakabayashi K, Ikuta F (1989) Correlative decrease of large neurons in the neostriatum and basal nucleus of Meynert in Alzheimer's disease. Brain Res 504:354-357.

Paxinos G, Watson C (1982) The rat brain in stereotaxic coordinates. New York: Academic.

Petrides PE, Shooter EM (1986) Rapid isolation of the 7S nerve growth factor complex, and its subunits from murine submaxillary gland and saliva. J Neurochem 46:721-725.

Pioro EP, Cuello AC (1988) Purkinje cells of adult cerebellum express nerve growth factor receptor immunoreactivity: light microscopical observations. Brain Res 455:182-186.

Pioro EP, Cuello AC (1990) Distribution of nerve growth factor receptor-like immunoreactivity in the adult rat central nervous system. Effect of colchicine and correlation with the cholinergic system-I. Forebrain. Neuroscience 34:57-87.

Raivich G, Kreutzberg GW (1987) The localization and distribution of high affinity B-nerve growth factor binding sites of the adult rat. A light microscopic autoradiographic study using ( $\left.{ }^{125} \mathrm{I}\right) \mathrm{B}$-nerve growth factor. Neuroscience 20:23-36.

Rea MA, Simon JR (1981) Regional distribution of cholinergic parameters within the rat striatum. Brain Res 219:317-326.

Richardson PM, Verge VMK, Riopelle RJ (1986) Distribution of neuronal receptors for nerve growth factor in the rat. J Neurosci 6:23122321.

Riopelle RJ, Richardson PM, Verge VMK (1987) Distribution and characteristics of nerve growth factor binding on cholinergic neurons of rat and monkey forebrain. Neurochem Res 12:923-928.
Schatteman GC, Gibbs L, Lanahan AA, Calude P, Bothwell M (1988) Expression of NGF receptor in the developing and adult primate central nervous system. J Neurosci 8:860-873.

Schoemaker H, Morelli M, Deshmuh P, Yamamura HI (1982) ['H]Ro 5-4864 benzodiazepine binding in the kainate lesioned striatum and Huntington's diseased basal ganglia. Brain Res 248:396-401.

Schwarcz R, Whetsell WO, Mangano RM (1983) Quinolinic acid: an endogenous metabolite that produces axon-sparing lesions in rat brain. Science 219:316-318.

Schweitzer JB (1989) Nerve growth factor receptor-mediated transport from CSF labels cholinergic neurons: direct demonstration by a double-labeling study. Brain Res 490:390-396.

Shelton DL, Reichardt LF (1986) Studies on the expression of beta NGF gene in the central nervous system: level and regional distribution of NGF mRNA suggest that NGF functions as a trophic factor for several neuronal populations. Proc Natl Acad Sci USA 83:27142718.

Springer JE (1988) Nerve growth factor receptors in the central ncrvous system. Exp Neurol 102:354-365.

Steele JC, Richardson JC, Olzewski J (1964) Progressive supranuclear palsy. Arch Neurol 10:333-359.

Strong R, Samorajski T, Gottesfeld Z (1982) Regional mapping of neostriatal neurotransmitter systems as a function of aging. J Neurochem 39:831-836.

Taniuchi MJ, Schweitzer JB, Johnson EM (1986) Nerve growth factor receptor molecules in the rat brain. Proc Natl Acad Sci USA 83:40944098.

Ternaux JP, Hery F, Bourgoin S, Adrien J, Glowinski J, Hamon M (1977) The topographical distribution of serotonergic terminals in the neostriatum of the rat and caudate nucleus of the cat. Brain Res 121:311-326.

Vantini G, Schiavo N, DiMartino A, Polato P, Triban C, Callcgaro L, Toffano G, Leon A (1989) Evidence for a physiological role of nerve growth factor in the central nervous system of neonatal rats. Neuron 3:267-272.

Woolf NJ, Gould E, Butcher LL (1989) Nerve growth factor receptor is associated with cholinergic neurons of the basal forebrain but not the pontomesencephalon. Neuroscience 30:143-152.

Yamamoto BK, Pehek A (1990) A neurochemical heterogeneity of the rat striatum as measured by in vivo electrochemistry and microdialysis. Brain Res 506:236-242. 